\title{
Variability and Inconsistency in Children with and Without Speech Sound Disorders
}

\author{
Seunghee Ha \\ Division of Speech Pathology and Audiology, Audiology and Speech Pathology Research Institute, Hallym University, Chuncheon, Korea
}

Correspondence: Seunghee Ha, PhD Division of Speech Pathology and Audiology, Audiology and Speech Pathology Research Institute, Hallym University, 1 Hallymdaehak-gil, Chuncheon 24252, Korea

Tel: +82-33-248-2215

Fax: $+82-33-256-3420$

E-mail: shha@hallym.ac.kr

Received: April 5, 2020

Revised: May 5, 2020

Accepted: May 5, 2020

This research has been supported by Hallym University Research Fund (HRF-202003-010).

\begin{abstract}
Objectives: This study aimed to quantify and examine consistent and correct word production in children with and without speech sound disorders (SSD) and by subgroups of SSD in order to differentiate between normal variability and inconsistent productions. Methods: This study included 209 typically developing children and 99 children with SSD. The children with SSD were classified into four subgroups based on linguistic symptomatology. All children were asked to produce 22 words on three separate occasions and their responses were categorized by four types and calculated into scores based on consistency and correctness of word production. This study examined whether proportion of each response and consistency-correctness scores reveal group and age differences. Results: Both children with and without SSD showed high proportions of consistent correct responses, which increased with age. Children produced more consistent correct responses and fewer variable-no hits as they got older. Children with SSD produced fewer consistent correct responses and more variable-no hits than typically developing children. Children with inconsistent phonological disorders produced the highest proportions of variable-no hits, differentiating from other three subgroups of SSD. Conclusion: This study indicated developmental patterns of normal variability by age and inconsistent phonological disorders showed atypical inconsistent productions which are different from normal variability. This study suggested a foundation for differential diagnosis of subgroups of SSD.
\end{abstract}

Keywords: Speech sound disorders, Normal variability, Atypical inconsistency, Age 비일관성(inconsistency)은 일반적인 조음음운 발달 과정 중에 서 관찰되는 변이성(variability)과는 구별되는 것으로, 아동기 말 실행증과 비일관적 음운장애를 진단할 수 있는 핵심적인 임상 표 지이다(Broomfield \& Dodd, 2004; Dodd, 2005; Holm, Crosbie, \& Dodd, 2007). 변이성은 말소리 습득 과정에서 목표 낱말 또는 음소 를 산출하기 위한 다양한 산출 시도의 결과로 아동의 조음음운체계 상의 미성숙 또는 제약으로 인해 발생한다(Grunwell, 1992; Holm et al., 2007; Sosa \& Stoel-Gammon, 2006; Sosa, 2015). 따라서 아동 의 말운동학적, 음운론적 체계가 안정적인 수준으로 발달하면 더 이상 관찰되지 않는 특징이다. 일반 아동을 대상으로 변이성의 발 달 패턴을 살펴본 국내외 연구는 공통적으로 일반 아동이 3-4세에 이르면 조음 변이성은 현저히 감소하고 낱말 및 음소 산출이 일관 적이고 안정적인 수행력을 보이기 시작한다고 보고하였다(Burt,
Holm, \& Dodd, 1999; Dodd, 1995; Holm et al., 2007; Hwang \& Ha, 2012; Kenny \& Prather, 1986; Teitzel \& Ozanne, 1999; Williams \& Stackhouse, 2000).

Dodd와 동료들은 3-6세 영국 아동들을 위한 『Diagnostic Evaluation of Articulation and Phonology, DEAP $($ Dodd, Zhu, Crosbie, Holm, \& Ozanne, 2002) 표준화 조음음운검사도구를 출판하 면서 일반과 말소리장애 아동들의 검사 결과를 토대로 언어학적 증상 또는 표면 오류 패턴을 바탕으로 말소리장애 하위 유형 분류 법을 제안하였다(Dodd, 1995; 2005). DEAP는 선별검사, 조음평가, 구강운동평가, 음운평가, 비일관성 평가 총 5 개의 하위 평가로 구성 되어 있다. 그 중 비일관성 검사는 25 개의 낱말을 세 번씩 산출하게 하는 과제로 Dodd (2005)의 말소리장애 하위 유형 중 비일관적 음 운장애를 감별 진단하는데 핵심적인 평가이다. DEAP에서는 세 번 
의 낱말 산출이 동일하면 0점, 상이한 산출이 한 번이라도 있다면 1 점으로 산정하였다. 아동이 25 개의 낱말 중 $40 \%$ 이상 즉, 10 개 이상 의 낱말을 서로 다른 형태로 산출한다면 비일관적 음운장애로 진 단하였다.

한편 국내에서는 조음기관의 구조 및 기능, 다양한 음절 길이와 구조에서의 음소 산출 능력, 낱말 산출의 일관성, 음운 기억 및 운 동 프로그래밍 등을 살펴보면서 평가 대상자의 조음음운능력의 강 - 약점을 종합적으로 평가하여 말소리장애를 감별진단하기 위 해 한국 조음음운프로파일(Korean Articulation and Phonology Profile, K-APP; $\mathrm{Ha}, \mathrm{Kim}, \mathrm{Seo}, \& \mathrm{Pi}$, in press) 검사도구가 개발되었 다. K-APP 검사도구는 (1) 조음기관 구조, (2) 조음기관 기능, (3) 낱 말 검사, (4) 무의미낱말 검사, (5) 연결발화 검사로 총 5가지 하위 평 가로 이루어져 있다. K-APP 검사의 하위 낱말 검사에는 Dodd 등 (2002)의 DEAP와 비슷하게 낱말의 일관성을 살펴보는 평가 단계 가 있다. 본 연구자는 선행연구에서 2 세 후반부터 9 세까지의 일반 과 말소리장애 아동을 대상으로 K-APP 검사의 낱말의 일관성 평 가 단계를 실시하여 조음 일관성의 발달 패턴을 살펴보고 병리적인 비일관성을 보이는 말소리장애를 감별 진단할 수 있는 기준점을 제 안하고자 하였다(Ha \& Seo, 2019). DEAP의 1점 체계와는 다소 다 르게 2점 체계를 바탕으로 3회 낱말 산출 기회 중 모두 다른 형태로 산출하였다면 0 점, 2 회만 동일하면 1점, 3 회 모두 동일하면 2점으로 산정하였다. 따라서 총 22 개의 검사어로 구성되어 있기 때문에 아 동이 모든 검사어를 동일한 형태로 산출하였다면 최고 점수인 44 점을 받게 된다. $\mathrm{Ha}$ 와 $\mathrm{Seo}$ (2019) 연구는 일관성 점수의 백분위수 자료에서 하위 $5 \%$ 에 해당하는 점수인 27점을 말소리 습득과정에 서 관찰되는 정상적인 변이성과 구별하여 병리적인 비일관성을 진 단하는 기준점(cutoff score)으로 제안하였다. 선행연구에서 병리적 인 비일관성을 구분하는 기준점으로 제안한 27점은 전체 일관성 점수에서 약 61.3\%에 해당하는 점수로 Dodd (1995)의 '비일관성 점수 $40 \%$ 와 거의 동일한 수준이다. 또한 27 점의 기준점을 사용하 여 선행연구에 포함된 말소리장애 140 명의 하위 유형을 분류한 결 과, 12 명 $(8.6 \%)$ 이 비일관적인 음운장애로 진단되었다. 이러한 비일 관적 음운장애 비율은 전체 말소리장애 아동 중 비일관적 음운장 애가 약 9\%를 차지하였다는 영국 자료(Broomfield \& Dodd, 2004) 와 거의 비슷한 수치를 보였다. 즉 선행 연구에서 비일관적 음운장 애를 진단하기 위해 제안한 일관성 점수의 기준점은 영국의 표준 화 연구 자료와 함께 조음 변이성과 비일관성에 대한 보편적인 경 향성을 반영한다고 할 수 있다.

병리적인 비일관성이 핵심적인 진단 표지가 되는 아동기 말 실행 증이나 비일관적 음운장애 아동은 정확한 진단뿐만 아니라 효과
적인 치료를 제공하는 데에 있어서 다른 말소리장애 유형에 비해 큰 어려움이 있다. 낱말 또는 음소 수준에서 비일관적인 산출을 보 이는 경우 음운 패턴 또는 규칙으로 아동의 오류를 파악하고 설명 하는 것이 제한적이다. 따라서 중재 목표 음소나 오류 패턴을 설정 하는 것이 쉽지 않고, 아동이 목표 음소를 습득하고 일반화하는 것 에 상대적으로 더 큰 어려움을 보인다. 또한 아동기 말 실행증이나 비일관적인 음운장애는 말 처리 과정에서 다른 말소리장애 하위 유형과 다른 단계 또는 기저 결함을 보이기 때문에 일반적으로 말 소리장애에게 효과적으로 사용되는 운동학습이론에 근거한 전통 적인 기법이나 음운대조를 이용한 언어학적 기법이 효과적이지 않 다(Berthal, Bankson, \& Flipsen, 2017; Dodd 2005). 따라서 아동기 말 실행증이나 비일관적인 음운장애에게 효과적인 치료법을 제공 하여 말 산출상의 어려움을 완화 또는 소거하기 위해서는 발달적 인 변이성과 구별하여 병리적인 비일관성을 정확하게 진단하는 것 이 중요하다. 궁극적으로 선행연구에서 제안된 병리적인 비일관성 을 진단하는 점수 체계와 기준점에 대한 지속적인 고찰과 임상적 유용성과 타당성을 점검하는 것이 필요하다.

Holm 등(2007)은 DEAP의 비일관성 평가의 표준화 자료를 토대 로 아동의 낱말 산출의 일관성을 보다 더 자세하게 이해하기 위해 일관성 정도를 정량화하여 특성을 자세히 분석하였다. 아동의 반 응을 일관성뿐만 아니라 정확도 측면을 동시에 고려하여 4 가지 반 응으로 분류하여 살펴보았다. 낱말 산출의 3 회 기회 중 모두 일관적 이고 정확한 반응(consistent correct response), 일관적이지만 모두 부정확한 반응(consistent incorrect response), 정확한 산출이 있지 만 변이적인 반응(variable with hits response), 모두 부정확하고 변 이적인 반응(variable - no hits response)으로 아동의 검사어 별 수 행력을 분석하였다. 연구결과 일반 아동은 변이적인 산출 특성을 보이기는 하나, 가장 연령이 낮았던 3세 아동의 비일관성 비율이 $13 \%$ 로 낮았으며, 변이적인 반응의 대부분도 정확하거나 부정확한 반응이 혼합되어 나타났다. 일반 아동은 일관적인 산출 특성이 더 두드러지게 나타나고 연령이 증가함에 따라 유의하게 감소하여 병 리적인 비일관성과 양과 질적으로 다름을 보여주었다. Holm 등 (2007)의 분석 방법은 낱말 산출의 정확성 여부와는 별도로 일관 성 측면만을 고려한 기존의 점수 체계보다 일관성과 정확성을 동시 에 고려하여 아동의 조음음운발달 수준과 능력에 대한 더 포괄적 인 정보를 제공하고 있다.

본 연구는 말소리 습득과정에서의 정상적인 변이성과 병리적인 비일관성을 구별하고자 낱말 산출의 일관성 및 정확성을 동시에 고려하고 정량화하여 연령에 따라 일반 아동과 말소리장애 아동 을 비교하여 살펴보고자 한다. 또한 표면 오류 패턴에 따라 분류한 
말소리장애 하위 유형 별로도 비교하여 병리적인 비일관성에 대해 살펴보고자 한다.

\section{연구방법}

\section{대상자}

본 연구는 2세 6개월부터 6세 11개월에 해당하는 일반 아동 209 명(남: 92명, 여: 117명)과 말소리장애 아동 99명(남: 64명, 여: 35명) 을 대상으로 진행하였다. 모든 연구 대상자는 K-APP 표준화 연구 에 참여하면서 K-APP 검사의 하위 검사 중 일관성 검사를 끝까지 수행한 아동 만을 포함하였다.

모든 대상자는 주양육자나 유치원 및 어린이집 교사의 보고에 기반하여 신체적, 인지적, 신경학적 발달 및 정서와 관련된 의학적 인 진단을 받지 않았으며, 청력 및 감각 발달에 문제가 없었다. 일반 아동은 아동용발음평가(APAC; Kim, Pae, \& Park, 2007)에서 백 분위수 16 이상인 경우에 해당하며, 말소리장애 아동은 APAC에 서 백분위수 16 이하에 해당하였다. 전체 대상자에 다문화 가정 아 동 8 명도 포함되었는데, 이 중 3 명이 말소리장애에 해당하였다. 일 반과 말소리장애 집단의 연령과 성별 분포는 Table 1과 같다.

말소리장애 집단은 Dodd (1995)가 제안한 말소리장애 하위유형 에 따라서 $\mathrm{Pi}$ 와 $\mathrm{Ha}$ (2020)에 기술된 절차와 동일한 방법과 기준으 로 평가 당시의 언어학적 증상에 따라 4 가지 하위 유형으로 분류하 였다. 본 연구에 포함된 총 99 명의 말소리장애 아동 중 1) 조음장애 (articulation disorder, AD)는 25명, 2) 음운 지연(phonological delay, PD)는 46명, 3) 일관적 음운장애(consistent phonological disorder, CPD)는 16명, 4) 비일관적 음운장애(inconsistent phonolog- ical disorder, IPD)는 12명으로 구성되었다.

\section{자료 수집 및 분석}

본 연구 자료는 2 음절에서부터 5 음절까지의 22 개 낱말로 구성된 K-APP의 일관성 검사를 실시하여 수집하였다. 아동에게 그림이름 대기 방식으로 검사어 문항 순서대로 1차적으로 제시한 후 다시 전 체 검사 문항을 순서대로 2 회씩 추가적으로 제시하여 낱말 당 총 세 번씩 산출할 수 있는 기회를 제공하였다. 자료 수집과 음성 전사 는 Ha와 Seo (2019)에 기술된 바대로 이루어졌다. 모든 아동의 반 응은 음성 녹음하였으며 모든 반응은 자료 수집 후 개별적으로 녹 음된 자료를 들으면서 음성 전사 후 분석하였다. 마찰음의 치간음 화와 같은 왜곡 오류는 평가 현장에서 표기하여 최종 음성 전사에 반영하였다. 청지각적으로 명확한 왜곡 오류에 한해서만 구별하고, 간략음성 전사(broad phonetic transcription)를 기본으로 하였다 (Holm et al., 2007).

음성 전사를 한 후 Holm 등(2007)의 연구를 참고하여 정확도와 일관성 여부를 토대로 아동의 검사어 별 모든 반응을 다음의 네 가 지 유형으로 분류하고, 낱말 산출의 발달적 경로를 고려하여 차등 적으로 점수를 부여하였다.

(1) 일관적이고 정확함(consistent correct): 동일한 낱말에 대한 세 번의 반응이 모두 동일하면서 정확한 경우로 3점을 부여하 였다.

(2) 정확한 산출이 있지만 변이적임(variable with hits): 세 번의 기회 중 서로 다른 형태의 낱말 산출이 관찰되었지만 정확하 게 산출한 낱말이 적어도 세 번의 기회 중 한 번이라도 있는 경우로 2점을 부여하였다.

Table 1. Participants' demographic characteristics

\begin{tabular}{|c|c|c|c|c|c|c|c|c|c|c|c|c|}
\hline \multirow{3}{*}{ Age } & \multirow{2}{*}{\multicolumn{2}{|c|}{$\begin{array}{l}\text { Typically developing } \\
\text { children }\end{array}$}} & \multicolumn{10}{|c|}{ Children with speech sound disorders } \\
\hline & & & \multicolumn{2}{|c|}{ Total } & \multicolumn{2}{|c|}{$A D$} & \multicolumn{2}{|c|}{ PD } & \multicolumn{2}{|c|}{ CPD } & \multicolumn{2}{|c|}{ ICPD } \\
\hline & $\mathrm{N}$ & Boy:girl & $\mathrm{N}$ & Boy:girl & $\mathrm{N}$ & Boy:girl & $\mathrm{N}$ & Boy:girl & $\mathrm{N}$ & Boy:girl & $\mathrm{N}$ & Boy:girl \\
\hline $2 ; 6-2 ; 11$ & 19 & $5: 14$ & & & & & & & & & & \\
\hline $3 ; 0-3 ; 5$ & 27 & 13:14 & 9 & $6: 3$ & & & 6 & $4: 2$ & & & 3 & $2: 1$ \\
\hline $3 ; 6-3 ; 11$ & 21 & 10:11 & 10 & $7: 3$ & & & 5 & $3: 2$ & 1 & $0: 1$ & 4 & $4: 0$ \\
\hline $4 ; 0-4 ; 5$ & 21 & $10: 11$ & 16 & $10: 6$ & & & 11 & $7: 4$ & 3 & $2: 1$ & 2 & $1: 1$ \\
\hline $4 ; 6-4 ; 11$ & 21 & $12: 9$ & 12 & 8:4 & & & 7 & $4: 3$ & 3 & $2: 1$ & 2 & $2: 0$ \\
\hline $5 ; 0-5 ; 5$ & 30 & $11: 19$ & 8 & $5: 3$ & 1 & $0: 1$ & 6 & $4: 2$ & 1 & $1: 0$ & & \\
\hline $5 ; 6-5 ; 11$ & 18 & $8: 10$ & 11 & $7: 4$ & 4 & $2: 2$ & 4 & $3: 1$ & 3 & $2: 1$ & & \\
\hline $6 ; 0-6 ; 5$ & 18 & $6: 12$ & 20 & $12: 8$ & 11 & $6: 5$ & 3 & $1: 2$ & 5 & $4: 1$ & 1 & $1: 0$ \\
\hline $6 ; 6-6 ; 11$ & 34 & $17: 17$ & 13 & $9: 4$ & 9 & 6:3 & 2 & $3: 1$ & & & & \\
\hline Total & 209 & $92: 117$ & 99 & $64: 35$ & 25 & 14:11 & 46 & 29:17 & 16 & $11: 5$ & 12 & $10: 2$ \\
\hline
\end{tabular}

$\mathrm{AD}=$ articulation disorder; $\mathrm{PD}=$ phonological delay; $\mathrm{CPD}=$ consistent phonological disorder; $\mathrm{ICPD}=$ inconsistent phonological disorder. 
(3) 일관적이지만 부정확함(consistent incorrect): 세 번의 낱말 산출이 모두 동일하지만 부정확한 경우로 1점을 부여하였다.

(4) 모두 부정확하고 변이적임(variable with no hits): 세 번의 기 회 중 서로 다른 형태의 낱말 산출이 관찰되었고 모두 부정확 한 경우로 0 점을 부여하였다.

아동 별로 4 가지 유형에 대한 빈도와 비율을 구하였고 검사어별 점수를 모두 더한 총점을 일관성 및 정확성 점수로 정하였다.

\section{신뢰도}

아동 반응에 대한 음성 전사의 정확성을 판단하기 위해 전체 자 료에서 무작위로 총 30 명의 자료를 선정하였다. K-APP 표준화 작 업에서 전체 아동 자료의 음성 전사 및 분석에 참여한 4 명의 전사 자에게 무작위로 선정한 음성 자료를 준 뒤 독립적으로 음성 전사 를 하게 하였다. 전사자 간 일치도는 4 명의 전사자를 각각 2 명씩 대 응(총 6쌍)하여 전체 자음 중 전사자 간 일치한 자음의 비율로 살펴 보았는데, 평균 $95.52 \%$ 의 전사자 간 일치도를 보였다.

\section{통계처리}

연령에 따라 말소리장애와 일반 아동 간 네 가지 반응 유형의 비 율과 일관성 및 정확도 점수에 차이가 있는지 살펴보기 위해 이원 분산분석(two-way ANOVA)을 실시하였다. 말소리장애 하위 유형 에 따라 네 가지 반응 유형의 비율과 일관성 및 정확도 점수에 차이 가 있는지는 일원분산분석(one-way ANOVA)을 통해 살펴보았다. 사후분석은 Bonferroni 검정을 실시하였다.

\section{연구결과}

\section{일반과 말소리장애 아동의 반응 비교}

일관성 검사에서 모든 연령대의 일반과 말소리장애 아동에게서 관찰된 네 가지 반응 유형별 비율은 Figure 1과 같다. 일반과 말소리 장애 아동의 연령에 따른 네 가지 반응 유형별 비율에 대한 기술통 계치는 Table 2 와 같다. 일반과 말소리장애 아동은 공통적으로 일 관적이고 정확한 반응을 가장 크게 보였다. 하지만 일반 아동과 비 교해 말소리장애 아동에게 일관적이고 정확한 반응의 비율의 크기 는 낮았으며, 나머지 부정확하거나 변이적인 반응은 더 높은 비율 로 나타났다.

\section{일관적이고 정확한 반응}

일관적이고 정확한 반응율의 경우 일반 아동 2세 후반은 $33.73 \%$

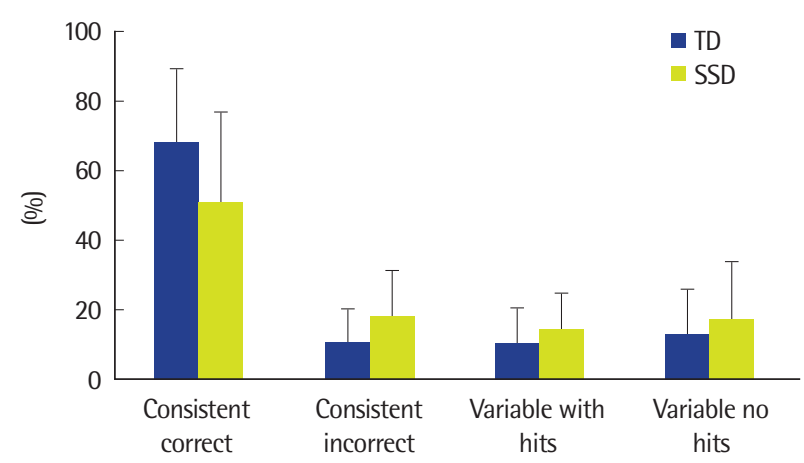

Figure 1. Percentage of each response in typically developing children.

Table 2. Descriptive results of percentage of responses in the consistency test at each age group in typically developing children (TD) and children with speech sound disorders (SSD)

\begin{tabular}{|c|c|c|c|c|c|c|c|c|}
\hline \multirow{3}{*}{ Age } & \multicolumn{4}{|c|}{ TD } & \multicolumn{4}{|c|}{ SSD } \\
\hline & \multicolumn{2}{|c|}{ Consistent (\%) } & \multicolumn{2}{|c|}{ Variable (\%) } & \multicolumn{2}{|c|}{ Consistent (\%) } & \multicolumn{2}{|c|}{ Variable (\%) } \\
\hline & Correct & Incorrect & With hits & No hits & Correct & Incorrect & With hits & No hits \\
\hline $2 ; 6-2 ; 11$ & $33.73(16.69)$ & $10.29(10.48)$ & $23.68(9.16)$ & $32.30(23.22)$ & & & & \\
\hline $3 ; 0-3 ; 5$ & $51.18(16.99)$ & $16.67(9.60)$ & $18.69(11.98)$ & 13.47 (12.57) & 25.76 (9.91) & 23.74 (17.12) & $16.67(8.50)$ & $33.33(14.19)$ \\
\hline $3 ; 6-3 ; 11$ & $54.98(12.85)$ & $21.21(9.57)$ & $12.99(8.29)$ & $10.82(9.26)$ & $27.27(15.45)$ & $15.91(10.11)$ & $19.09(7.36)$ & $37.73(18.81)$ \\
\hline $4 ; 0-4 ; 5$ & 72.08 (13.20) & 9.09 (8.26) & 12.99 (8.78) & 5.85 (8.76) & 39.77 (17.53) & 22.44 (10.29) & $17.05(7.87)$ & $20.74(15.21)$ \\
\hline $4 ; 6-4 ; 11$ & 72.73 (13.79) & $11.04(9.60)$ & $12.56(7.86)$ & $3.68(5.86)$ & 39.39 (23.92) & $27.65(19.13)$ & $18.94(12.23)$ & $14.02(19.90)$ \\
\hline $5 ; 0-5 ; 5$ & $77.88(13.01)$ & $8.79(9.62)$ & $11.37(8.83)$ & $1.97(2.85)$ & 59.66 (16.01) & $14.78(7.19)$ & $14.78(6.31)$ & $10.80(7.26)$ \\
\hline $5 ; 6-5 ; 11$ & 79.04 (11.78) & $4.29(6.33)$ & $15.91(11.48)$ & $0.76(1.74)$ & $59.92(20.51)$ & $18.59(10.26)$ & $10.75(8.20)$ & $10.75(10.81)$ \\
\hline $6 ; 0-6 ; 5$ & 78.03 (15.92) & $6.06(6.97)$ & $12.12(11.02)$ & $3.79(4.48)$ & $65.68(28.15)$ & 12.50 (13.01) & $12.05(10.25)$ & 9.77 (12.62) \\
\hline $6 ; 6-6 ; 11$ & $85.29(10.32)$ & 5.62 (5.93) & 7.49 (6.89) & $1.61(2.94)$ & $73.43(19.53)$ & $9.79(8.27)$ & $10.49(13.30)$ & $6.29(7.99)$ \\
\hline Whole & $68.33(20.76)$ & $10.31(9.85)$ & $13.70(10.23)$ & 7.66 (12.94) & $50.69(26.11)$ & $17.82(13.43)$ & $14.69(9.99)$ & 16.76 (16.98) \\
\hline
\end{tabular}

Values are presented as mean (SD). 
로 나타났으며 연령과 함께 점진적으로 증가하여 4세 전반에 $72.08 \%$ 였고, 6세 후반에는 $85.29 \%$ 로 가장 높은 반응률을 보였다. 말소리 장애 아동도 연령이 증가함에 따라 일관적이고 정확한 반응은 증 가하는 패턴을 보이기는 하였으나, 3세 전반에 일관적이고 정확한 반응률이 $25.76 \%$ 로 나타나 동일 연령대의 일반 아동에 비해 많이 낮았다. 두 집단 간 연령에 따른 일관적이고 정확한 반응의 비율이 통계적으로 유의한 차이를 보이는지 분석한 결과, 집단 $\left(F_{(1,291)}=\right.$ $\left.115.642, p<.001, \eta_{\mathrm{p}}{ }^{2}=.284\right)$ 과 연령 $\left(F_{(8,291)}=33.462, p<.001, \eta_{\mathrm{p}}{ }^{2}=.284\right)$ 간 주 효과와 집단 및 연령 간 상호작용효과 $\left(F_{(7,291)}=2.268, p<.05\right.$, $\left.\eta_{\mathrm{p}}{ }^{2}=.052\right)$ 모두 유의하였다. 일반 및 말소리장애 집단과 연령 간 상 호작용효과를 구체적으로 알아보기 위해 두 집단 별로 연령에 따 른차이를 일원분산분석을 실시한 결과 일반 $\left(F_{(8,200)}=33.651, p<.001\right.$, $\left.\eta_{\mathrm{p}}{ }^{2}=.574\right)$ 과 말소리장애 집단 $\left(F_{(7,91)}=8.994, p<.001, \eta_{\mathrm{p}}{ }^{2}=.409\right)$ 모 두 연령 간 유의미한 차이가 나타났다. 각 집단 별로 사후분석을 실 시한 결과, 먼저 일반 아동의 경우 2 세 후반은 모든 집단과 유의미 한 차이를 보였으며, 3 세 전반과 3 세 후반은 각각 인접한 3 세 집단 을 제외한 모든 연령 집단과 차이를 보였다. 4 세 전반과 후반은 4 세 이전의 연령이 낮은 모든 집단과 유의한 차이를 보이고 연령이 높 은 5-6세 집단과는 유의한 차이를 보이지 않았다. 말소리장애 아동 은 3 세 전반과 후반은 5 세 전반 이상의 연령과 유의미한 차이를 보 이고 4 세 전반과 후반은 6 세 전반과 후반과 유의미한 차이를 보였 다. 5 세와 6 세는 서로 연령 간 유의미한차이를 보이지 않았다.

\section{일관적이지만 부정확한 반응}

일반과 말소리장애 집단 간 연령에 따른 일관적이지만 부정확한 반응율에 대한 통계분석결과, 집단 $\left(F_{(1,291)}=37.245, p<.001, \eta_{\mathrm{p}}{ }^{2}=.113\right)$ 과 연령 $\left(F_{(8,291)}=6.532, p<.001, \eta_{\mathrm{p}}{ }^{2}=.152\right)$ 간 주 효과와 집단 및 연 령 간 상호작용효과 $\left(F_{(7,291)}=3.556, p=.001, \eta_{\mathrm{p}}{ }^{2}=.079\right)$ 모두 유의하 였다. 일반 및 말소리장애 집단과 연령 간 상호작용효과를 구체적 으로 알아보기 위해 두 집단별로 연령에 따른 차이를 일원분산분 석을 실시한 결과 일반 $\left(F_{(8,200)}=9.188, p<.001, \eta_{\mathrm{p}}{ }^{2}=.269\right)$ 과 말소리 장애 집단 $\left(F_{(7,91)}=3.028, p=.007, \eta_{\mathrm{p}}{ }^{2}=.189\right)$ 모두 연령 간 유의미한 차이가 나타났다. 각 집단별로 사후분석을 실시한 결과, 일반 아동 은 2 세 후반은 3 세 후반과만 유의미한 차이를 보이고 3 세 전반은 5 세 전반의 높은 연령과 유의미한 차이를 보였다. 3 세 후반은 3 세 전 반을 제외한 모든 연령과 4 세 전반과 후반은 3 세 후반만 유의미한 차이를 보였다. 5 세 전반과 후반은 3 세 전반과 후반을 제외한 모든 연령과 유의미한 차이를 보이지 않았다. 말소리장애 아동은 4 세 후 반과 6세 전반 및 후반의 연령 대응 비교만이 유의미한 차이를 보 였다.

\section{정확한 산출이 있지만 변이적인 반응}

두 집단 간 연령에 따른 정확한 산출이 있지만 변이적인 반응 비 율에 대한 통계분석결과는 연령에 대한 주 효과만 유의미하였다 $\left(F_{(8,291)}=5.151, p<.001, \eta_{\mathrm{p}}{ }^{2}=.124\right)$. 연령에 따른 사후분석 결과, 2 세 후반은 5 세 이상의 연령과 3 세 전반은 6 세 후반과만 유의미한 차이 를 보이고, 그 외의 연령 대응 비교는 차이가 유의미하지 않았다.

\section{모두 부정확하고 변이적인 반응}

모두 부정확하고 변이적인 반응율은 일반 아동의 경우에는 2세 후반이 $32.30 \%$ 로 가장 높게 나타났으며 연령과 함께 점진적으로 감소하여 3 세 전반과 후반은 각각 $13.47 \%, 10.82 \%$ 를 보이다가 4 세 전반부터는 $10 \%$ 미만의 낮은 비율을 보였다. 말소리장애 아동은 3 세 전반과 후반이 각각 $33.33 \%, 37.73 \%$ 로 가장 높다가 연령이 증가 함에 따라 비율이 감소하여 6 세에는 $10 \%$ 미만의 비율을 보였다. 두 집단 간 연령에 따른 모두 부정확하고 변이적인 반응 비율에 대한 통계분석 결과는 집단 $\left(F_{(1,291)}=77.688, p<.001, \eta_{\mathrm{p}}{ }^{2}=.211\right)$ 과 연령 $\left(F_{(8,291)}=25.562, p<.001, \eta_{\mathrm{p}}{ }^{2}=.413\right)$ 간 주 효과와 집단 및 연령 간 상호작용효과 $\left(F_{(7,291)}=3.355, p=.002, \eta_{\mathrm{p}}{ }^{2}=.075\right)$ 모두 유의하였다. 일반 및 말소리장애 집단과 연령 간 상호작용효과를 구체적으로 알아보기 위해 두 집단별로 연령에 따른 차이를 일원분산분석을 실시한 결과, 일반 $\left(F_{(8,200)}=21.966, p<.001, \eta_{\mathrm{p}}{ }^{2}=.468\right)$ 과 말소리장 애 집단 $\left(F_{(7,91)}=7.453, p<.001, \eta_{\mathrm{p}}=.364\right)$ 모두 연령 간 유의미한 차 이가 나타났다. 각 집단별로 사후분석을 실시한 결과, 일반 아동의 경우 2 세 후반은 모든 집단과 유의미한 차이를 보였으며, 3 세 전반 은 4세 후반 이상의 높은 연령과도 유의미한 차이를 보였고, 그 외 의 연령 대응 비교는 차이가 유의미하지 않았다. 말소리장애 아동 은 3 세 전반은 5 세 전반 이상의 연령과, 3 세 후반은 4 세 후반 이상 의 연령과 유의미한 차이를 보였으며, 그 외의 연령 대응 비교는 유 의한차이를 보이지 않았다.

\section{일관성 및 정확도 점수}

낱말 산출의 정확성과 일관성을 동시에 고려하여 3점 척도로 아 동의 22 개 검사어별 반응을 평정한 점수의 결과는 Table 3 과 같다. 일반 아동의 경우 2 세 후반에는 34.95 였으며 연령이 증가함에 따라 증가하여 6세 후반에는 60.82 로 대부분의 검사어에서 정확하고 일 관적인 반응을 보이는 것으로 나타났다. 말소리장애도 점수는 낮 지만 3세 전반이 29.44이고 6세 후반에는 55.23으로 연령이 증가함 에 따라 증가하는 추세를 보였다. 두 집단 간 연령에 따른 차이를 살 펴본 결과, 집단 $\left(F_{(1,291)}=133.183, p<.001, \eta_{\mathrm{p}}{ }^{2}=.314\right)$ 과 연령 $\left(F_{(8,291)}=\right.$ $\left.35.242, p<.001, \eta_{\mathrm{p}}{ }^{2}=.492\right)$ 간 주 효과와 집단 및 연령 간 상호작용 
효과 $\left(F_{(7,291)}=2.600, p<.05, \eta_{\mathrm{p}}^{2}=.059\right)$ 모두 유의하였다. 일반 및 말 소리장애 집단과 연령 간 상호작용효과를 구체적으로 알아보기 위 해 두 집단 별로 연령에 따른 차이를 일원분산분석을 실시한 결과, 일반 $\left(F_{(8,200)}=33.742, p<.001, \eta_{\mathrm{p}}{ }^{2}=.574\right)$ 과 말소리장애 집단 $\left(F_{(7,91)}=\right.$ $\left.9.554, p<.001, \eta_{\mathrm{p}}{ }^{2}=.424\right)$ 모두 연령 간 유의미한 차이가 나타났다. 각 집단 별로 사후분석을 실시한 결과, 먼저 일반 아동의 경우 2 세 후반은 모든 집단과 유의미한 차이를 보였으며, 3세 전반과 3세 후 반은 각각 인접한 3 세 집단을 제외한 모든 연령 집단과 차이를 보였 다. 4 세 전반과 후반은 4 세 이전의 2 세와 3 세 모든 집단과 유의한 차이를 보이고 연령이 높은 5-6세 집단과는 유의한 차이를 보이지 않았다. 말소리장애 아동은 3 세 전반과 후반은 5 세 전반 이상의 연 령과 유의미한 차이를 보이고 4 세 전반과 후반은 6세 전반과 후반 과 유의미한 차이를 보였다. 5 세와 6 세는 서로 연령 간 유의미한 차 이를 보이지 않았다 $(p<.05)$.

Table 3. Descriptive results of consistency-correctness scores at each age group in typically developing children (TD) and children with speech sound disorders (SSD)

\begin{tabular}{lll}
\hline \multirow{2}{*}{ Age } & \multicolumn{2}{c}{ Consistency-correctness scores* } \\
\cline { 2 - 3 } & \multicolumn{1}{c}{ TD } & \multicolumn{1}{c}{ SSD } \\
\hline $2 ; 6-2 ; 11$ & $34.95(13.38)$ & \\
$3 ; 0-3 ; 5$ & $45.67(8.65)$ & $29.44(6.48)$ \\
$3 ; 6-3 ; 11$ & $46.67(6.42)$ & $29.90(10.61)$ \\
$4 ; 0-4 ; 5$ & $55.29(6.70)$ & $38.69(9.84)$ \\
$4 ; 6-4 ; 11$ & $55.95(6.18)$ & $40.42(13.45)$ \\
$5 ; 0-5 ; 5$ & $58.33(5.17)$ & $49.13(7.42)$ \\
$5 ; 6-5 ; 11$ & $60.11(3.34)$ & $48.36(10.32)$ \\
$6 ; 0-6 ; 5$ & $58.17(5.94)$ & $51.40(13.30)$ \\
$6 ; 6-6 ; 11$ & $60.82(3.75)$ & $55.23(8.21)$ \\
Whole & $53.40(10.47)$ & $43.83(13.58)$ \\
\hline
\end{tabular}

Values are presented as mean (SD).

*Possible highest scores $=66$.

\section{말소리장애 하위 유형별 일관성 및 정확도 반응}

일관성 검사에서 말소리장애 하위 유형별 일관성 및 정확도에 대한 분석 결과는 Table 4 와 같다. 말소리장애 하위 유형별 아동에 게서 관찰된 4 가지 반응 유형의 비율은 Figure 2 와 같다. 말소리장 애 하위 유형 중 조음장애, 음운지연, 그리고 일관적 음운장애는 공통적으로 일관적이고 정확한 반응의 비율이 가장 높게 나타났고 다음으로 일관적이지만 부정확한 반응이 높게 나타났다. 하지만 비 일관적 음운장애는 3 회 산출한 낱말이 모두 부정확하고 비일관적 인 반응이 가장 높고 다음으로 정확한 산출이 있지만 변이적인 반 응이 높게 나타나 다른 세 하위 유형의 말소리장애 아동과 구별되 는수행력을 보였다.

반응 유형에 따라 말소리장애 하위 유형 간 차이가 있는지 살펴 본 결과, 일관적이고 정확한 반응은 하위 유형 간 차이가 유의미한 차이가 나타났다 $\left(F_{(3,95)}=25.250, p<.001, \eta_{\mathrm{p}}{ }^{2}=.444\right)$. 다중 비교를 위한 수정된 Bonferroni 사후 분석 결과, 음운지연과 일관적인 음 운장애 만이 서로 유의미한 차이가 나타나지 않았고 조음장애는 다른 세가지 말소리장애 유형에 비해 유의하게 높고, 비일관적인 음운장애는 유의하게 낮았다. 정확한 산출이 있지만 변이적인 반 응도 하위 유형 간 차이가 유의미한 차이가 나타났다 $\left(F_{(3,95)}=5.335\right.$,

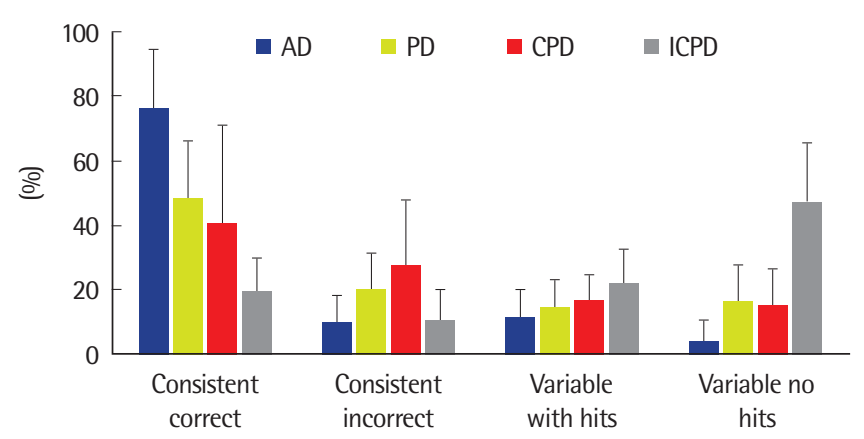

Figure 2. Percentage of each response in subgroups of children with speech sound disorders (SSD).

Table 4. Descriptive results of percentage of responses and consistent-correctness scores in the consistency test by subgroups of children with speech sound disorders

\begin{tabular}{|c|c|c|c|c|c|c|}
\hline \multirow{2}{*}{ Group } & \multirow{2}{*}{$\mathrm{N}$} & \multicolumn{2}{|c|}{ Consistent (\%) } & \multicolumn{2}{|c|}{ Variable (\%) } & \multirow{2}{*}{$\begin{array}{c}\text { Consistent-correctness } \\
\text { scores }\end{array}$} \\
\hline & & Correct & Incorrect & With hits & No hits & \\
\hline$A D$ & 25 & 76.18 (18.38) & $10.00(7.87)$ & $9.46(10.97)$ & $4.36(6.36)$ & 56.64 (7.36) \\
\hline PD & 46 & 48.42 (17.78) & 20.55 (10.66) & $14.82(8.54)$ & $16.11(11.72)$ & 42.98 (9.61) \\
\hline CPD & 16 & $40.63(30.17)$ & $27.56(20.22)$ & $17.05(7.70)$ & $14.77(11.79)$ & 40.37 (14.32) \\
\hline ICPD & 12 & $19.70(10.32)$ & $10.61(9.16)$ & $21.97(10.94)$ & 47.73 (18.03) & 25.00 (9.32) \\
\hline
\end{tabular}

Values are presented as mean (SD).

$\mathrm{AD}=$ articulation disorder; $\mathrm{PD}=$ phonological delay; $\mathrm{CPD}=$ consistent phonological disorder; $\mathrm{ICPD}=$ inconsistent phonological disorder. 
$\left.p=.002, \eta_{\mathrm{p}}{ }^{2}=.144\right)$. 사후분석 결과, 비일관적인 음운장애가 조음 장애 보다 유의하게 높은 비율을 보였다.

일관적이지만 부정확한 반응도 말소리장애 하위 유형 간 유의미 한 차이를 보였다 $\left(F_{(3,95)}=9.304, p=.002, \eta_{\mathrm{p}}{ }^{2}=.227\right)$. 사후분석 결 과, 음운지연과 일관적 음운장애는 조음장애와 비일관적 말소리장 애에 비해 일관적이지만 부정확한 반응의 비율이 유의하게 높았다. 모두 부정확하고 변이적인 반응도 역시 하위 유형 간 차이가 유의 미하였다 $\left(F_{(3,95)}=38.126, p<.001, \eta_{\mathrm{p}}{ }^{2}=.546\right)$. 사후분석 결과, 조음 장애는 다른 세 하위 유형에 비해 부정확하고 변이적인 반응이 유 의하게 낮았으며, 비일관적 음운장애는 다른 세 하위 유형에 비해 유의하게 높았다.

낱말 산출의 정확성과 일관성 여부를 차등적으로 점수를 매긴 일관성 및 정확성 점수는 조음장애가 56.64로 가장 높았으며, 비일 관적인 음운장애가 25 로 가장 낮은 점수를 보였다. 일원분산분석 결과, 말소리장애 하위 유형에 따라 총점이 유의미한 차이를 보였 다 $\left(F_{(3,95)}=28.658, p<.001, \eta_{\mathrm{p}}{ }^{2}=.475\right)$. 사후분석 결과, 음운지연과 일관적인 음운장애만이 서로 유의미한 차이가 나타나지 않았고 다 른 하위 유형 간에는 유의미한 차이가 나타났다. 즉 조음장애는 다 른 하위 유형에 비해 높은 점수를 보였으며, 비일관적인 음운장애 는 다른 하위 유형에 비해 유의하게 낮은 점수를 보였다.

\section{논의 및 결론}

본 연구는 조음음운발달 과정에서 관찰되는 정상적인 변이성과 비교하여 일부 말소리장애 아동이 보이는 병리적 비일관성을 구별 하고자 하였다. 일반 아동과 말소리장애 아동을 대상으로 낱말을 3 회씩 산출하게 한 후 낱말 산출의 일관성과 정확성을 동시에 고려 하여 아동의 반응을 4 가지로 분류하여 집단과 연령 간 특성을 자 세히 살펴보았다. 4 가지 반응 유형 중에서 정확한 산출은 있지만 변 이적인 반응을 제외한 나머지 3가지 반응 유형은 모두 일반과 말소 리장애 아동 간 유의한 차이를 보였으며, 4 가지 반응 유형 모두에 서 연령에 대한 주 효과는 유의하였다. 따라서 일반과 말소리장애 아동 간의 유의한 차이가 없는 “정확하지만 변이적인 반응”은 병리 적이라기 보다는 말소리 발달 과정에서 온전한 성인 음운체계로 나 아가는 중간 과정으로 음운체계 상의 변화 또는 성숙을 반영한다 고 할수 있다(Holm et al., 2007).

일반 아동의 연령 별 조음 일관성 발달 패턴 결과를 살펴보면, 일 반 아동은 연령이 증가함에 따라 점진적으로 일관적이고 정확한 반응의 비율은 증가하고, 정확하거나 부정확하면서 변이적인 반응 의 비율은 유의하게 감소하는 모습을 보였다. 2 세 후반은 일관적이
고 정확한 반응이 $33.73 \%$ 로 4 가지 반응 중에서 가장 높은 비율을 차지하기는 하였으나, 부정확하고 변이적인 반응과 정확한 산출이 있지만 변이적인 반응의 비율도 각각 $32.30 \%, 23.68 \%$ 로 비슷하게 나타났다. 일관적이고 정확한 반응의 비율은 4세 전반에는 $72.08 \%$ 으로 증가해 연령이 낮은 2-3세 모든 집단과 유의한 차이를 보이고 연령이 높은 5-6세 집단과는 유의한 차이를 보이지 않았다. 정확한 산출이 있지만 변이적인 반응의 경우 2 세 후반은 5 세 이상의 연령 과 3 세 전반은 6 세 후반과 비교해 유의하게 높아 2 세 후반과 3 세 전 반이 변이적인 산출이 두드러지게 나타났다. 이러한 4 가지 반응율 에 나타난 발달 특성은 낱말 산출의 정확성과 일관성 여부를 바탕 으로 4 가지 반응을 차등적으로 점수를 매긴 후에 분석한 일관성 및 정확성 점수에 종합적으로 나타났다. 22 개의 검사어가 모두 정 확하고 일관적인 산출일 경우의 66점과 비교해서 일반 아동은 2세 후반에 34.95점을 보였으며 연령이 증가함에 따라 증가하여 4세에 는 약 55 점, 5 세 이후에는 58 점대를 보이면서 대부분의 검사어에서 정확하고 일관적인 반응을 보이는 것으로 나타났다. 따라서 일반 아동의 4 가지 반응 비율과 일관성 및 정확성 점수 결과를 종합해보 면 2세 후반과 3 세 전반에는 조음음운발달상의 제약으로 인해 일 부 검사어에서 정확성이 떨어지거나 다양한 형태로 낱말을 산출하 는 특성이 두드러지게 나타났다. 4 세가 되면 낱말 산출의 일관성과 정확성 측면이 연령이 높은 아동과 비슷한 수준에 도달하여 안정 적인 수행력을 보이기 시작했다. 따라서 2 세 후반과 3 세 전반의 일 반 아동이 보인 변이적인 산출은 성인의 조음음운체계로 나아가 는 과정에서 관찰되는 음운습득전략으로서 간주할 수 있다(Dyson \& Paden, 1983; Grunwell, 1992; Holm et al., 2007). 또한 본 연구 의 결과는 3-4세에 조음 일관성이 유의하게 증가한다는 국내외 선 행연구 결과와 더불어 4 세가 되면 낱말 산출의 일관성과 정확성 모 두에서 두드러진 발달을 보인다는 것을 지지하고 있다(Burt et al., 1999; Dodd, 1995; Ha \& Seo, 2019; Hwang \& Ha, 2012; Holm et al., 2007; Kenny \& Prather, 1986; Teitzel \& Ozanne, 1999; Williams \& Stackhouse, 2000).

말소리장애 아동은 일반 아동과 같이 연령이 증가함에 따라 일 관적이고 정확한 반응이 증가하고, 변이적인 반응은 감소하는 발 달적 경향을 보였다. 하지만 3 세 전반과 후반의 경우 4 가지 반응 유 형 중 3 개의 낱말 모두 부정확하면서 변이적인 반응이 각각 $33.33 \%$, $37.73 \%$ 로 가장 높게 나타나 상대적으로 정확하거나 부정확하면서 일관적인 반응은 낮아 일반 아동에 비해 조음 정확도뿐만 아니라 일관성 측면에서도 떨어지는 발달 수준을 보였다. 일관성 및 정확 성 점수는 3세에는 29점대를 보이다가 점진적으로 증가하였지만 6 세 후반에도 55점으로 일반 아동에 비해 낮은 점수를 보였다. 4 가 
지 반응 유형과 일관성 및 정확성 점수에 대한 사후분석을 종합해 보면 말소리장애 아동은 5 세에 이르러 어린 연령과 유의하게 차이 를 보이고 6세와는 반응 비율의 차이가 없는 것으로 나타나 본 연 구에 포함된 말소리장애 아동은 5 세에 이르러 낱말 산출의 일관성 과 정확성 측면이 안정적인 수행력을 보였다.

말소리장애는 기저원인, 증상, 유지 및 관련 요인 측면에서 다양 하기 때문에 말소리장애 아동의 전체 수행력보다는 하위 유형 별 로 수행력과 특성을 살펴보는 것이 더 적절하다. 따라서 본 연구에 서는 Dodd (2005)가 제안한 표면 오류 패턴을 바탕으로 말소리장 애 아동을 4 가지 하위 유형으로 나눈 후에 일관성 검사에서의 수 행력을 추가적으로 살펴보았다. 특히 비일관적 음운장애의 경우는 현재 출판 중에 있는 K-APP를 이용하여 본 Ha \& Seo (2019)에서 제안한 일관성 점수의 기준점을 기반으로 분류 및 감별 진단하였 다. 본 연구에서 평정한 낱말 산출의 일관성 및 정확성 점수는 조음 장애의 경우 56.64점으로 가장 높았으며, 비일관적인 음운장애가 25점으로 가장 낮은 점수를 보였다. 또한 비일관적인 음운장애는 다른 말소리장애 하위 유형과 구별되게 4 가지 반응 유형 중 모두 부 정확하고 비일관적인 반응이 가장 높았으며, 다음으로 정확한 산 출이 있지만 변이적인 반응이 높게 나타났다. 이러한 결과는 일반 아동과 비교해 조음장애, 음운지연, 일관적 음운장애는 변이성이 높지만 그 정도가 약하다. 반면에 비일관적인 음운장애는 조음 정 확도와함께 일관성이 현저히 떨어져서 조음음운 발달 과정에서 보 이는 정상적인 변이성과는 다른 병리적인 비일관성을 보인다고 할 수 있다. 따라서 본 연구결과는 비일관적인 음운장애는 일반 아동 뿐만 아니라 다른 말소리장애 아동과는 다른 집단임을 확증하고 있다(Holm et al., 2007; Dodd, 2005).

본 연구에서 나타난 다른 말소리장애 하위 유형과 구별되어 비일 관적 음운장애에게서 나타난 결과는 병리적인 비일관성을 감별 진 단하기 위해 Ha와 Seo (2019)에서 제시한 일관성 점수의 기준점이 타당하다는 것을 간접적으로 제안하고 있다. 하지만 동시에 $\mathrm{Ha}$ 와 Seo (2019)에서 제시한 점수 체계에 대해서는 보다 더 면밀히 재고 해야 함을 제안하고 있다. $\mathrm{Ha}$ 와 $\mathrm{Seo}$ (2019)에서는 비일관적인 음운 장애를 진단하기 위한 기준점으로 조음 정확도와 상관없이 3회 낱 말 산출의 기회 중 모두 다른 형태로 산출한다면 0 점을, 2 회만 동일 하게 산출한다면 1점을, 3 회 모두 동일한 형태로 산출한다면 2점으 로 처리하였다. 따라서 본 연구에서 “정확한 산출이 있지만 변이적 인 반응”이 “모두 부정확하고 변이적인 반응” 과 구별이 안되고 동 일하게 0 점이나 1 점으로 산정되어, 조음음운발달 측면에서 보다 더 긍정적인 것으로 해석할 수 있는 "정확한 산출이 있지만 변이적인 반응”을 과소평가하게 된다. 반대로 본 연구에서 “일관적이지만 부
정확한 반응” 의 경우도 “일관적이고 정확한 반응” 과 동일하게 2점 으로 산정되어 아동의 조음 일관성이 과대평가 될 수 있다. 따라서 본 연구에서 사용한 일관성뿐만 아니라 정확성 여부도 동시에 반 영하는 3점 체계가 아동의 조음음운발달 수준과 과정을 좀 더 타 당하게 평가할 수 있다. 추후 점수체계 및 기준에 대한 보다 체계적 인 분석과 비교를 통해서 표면 오류 패턴에 따른 말소리장애 하위 유형 분류를 위한 기준점을 정립해 나가야 할 것이다. 그리고 일반 적으로 일반과 말소리장애 아동 모두 검사어의 조음 복잡성이 증 가할수록 변이성이 증가함으로(Han \& Ha, 2017; McLeod \& Hewett, 2008; Sosa \& Stoel-Gammon, 2012) 후속 연구에서는 검사어의 길 이 및 구조, 조음 난이도와 같은 검사어의 음운특성에 따라 변이성 이 어떠한 특징을 보이는지 살펴볼 필요가 있다. 특히 본 연구에서 사용한 검사도구는 2 음절에서부터 점진적으로 길이와 음절구조 가 복잡해지는 낱말로 구성되어 있기 때문에 일반 아동과 말소리 장애 아동 간의 변이적인 산출이 어떠한 양상을 보이는지 비교할 수 있겠다. 특히 비일관적인 조음 산출이 핵심적인 말 특징인 아동 기 말 실행증과 비일관적인 음운장애 아동 군이 다른 말소리장애 유형과 비교하여 검사어의 길이와 음절구조에 대해 어떠한 반응을 보이는지 체계적으로 살펴볼 필요가 있겠다. 그러한 연구는 아동기 말 실행증과 비일관적 음운장애가 보이는 비일관성의 기저 원인 및 관련 요인을 탐구하는 것이 되고, 궁극적으로 해당 말소리장애 유 형에게 효과적인 중재 기법을 찾는데 중요한 시사점이 있다.

결론적으로 본 연구는 선행연구에서 정상적인 변이성과 병리적 인 비일관성을 구분하는 기준점으로 분류된 비일관적인 음운장애 는 일반적인 조음음운 발달 과정 중에서 관찰되는 변이성(variability)과는 다르게 정확성도 낮으면서 비일관적인 산출이 많은 특성 을 보임을 제안하고 있다. 이러한 결과는 말소리장애의 감별 진단 의 기반을 마련하고 있다.

\section{REFERENCES}

Bernthal, J., Bankson, N., \& Flipsen, P. (2017). Articulation and phonological disorders: speech sound disorders in children (8th ed.). Boston, MA: Pearson.

Burt, L., Holm, A., \& Dodd, B. (1999). Phonological awareness skills of 4-yearold British children: an assessment and developmental data. International Journal of Language \& Communication Disorders, 34(3), 311-335.

Broomfield, J., \& Dodd, B. (2004). The nature of referred subtypes of primary speech disability. Child Language Teaching and Therapy, 20(2), 135-151.

Dodd, B. (1995). Differential diagnosis and treatment of children with speech disorder. London: Whurr. 
Dodd, B. (2005). Differential diagnosis \& treatment of children with speech disorder (2nd ed.). London: Whurr.

Dodd, B., Zhu, H., Crosbie, S. Holm, A., \& Ozanne, A. (2002). Diagnostic Evaluation of Articulation and Phonology (DEAP). London: Pearson.

Dyson, A. T., \& Paden, E. P. (1983). Some phonological acquisition strategies used by two-year-olds. Journal of Childhood Communication Disorders, 7(1), 6-18.

Grunwell, P. (1992). Processes of phonological change in developmental speech disorders. Clinical Linguistics \& Phonetics, 6(1-2), 101-122.

Ha, S., Kim, M., Seo, D. G., \& Pi, M. (in press). Korean Articulation Phonology Profile. Seoul: Human Brain Research and Consulting.

Ha, S., \& Seo, D. G. (2019). Articulatory consistency for differential diagnosis of speech sound disorders. Communication Sciences \& Disorders, 24(4), 1015-1025.

Han, E. J., \& Ha, J. W. (2017). Variability of speech sound production according to phonetic complexity in children with and without speech sound disorders. Communication Sciences and Disorders, 22(4), 772-783.

Holm, A., Crosbie, S., \& Dodd, B. (2007). Differentiating normal variability from inconsistency in children's speech: normative data. International Journal of Language \& Communication Disorders, 42(4), 467-486.

Hwang, J., \& Ha, S. (2012). A study of articulatory variation in typically developing children between 2 and 4 years of age. Korean Journal of Communication \& Disorders, 17(3), 403-413.

Kenny, K., \& Prather, E. (1986). Articulation development in preschool children: consistency of production. Journal of Speech and Hearing Research,
29(1), 29-36.

Kim, M. J., Pae, S. Y., \& Park, C. I. (2007). Assessment of phonology and Articulation for Children (APAC). Incheon: Human Brain Research and Consulting.

McLeod, S., \& Hewett, S. R. (2008). Variability in the production of words containing consonant clusters by typical 2- and 3-year-old children. Folia Phoniatrica et Logopaedica, 60(4), 163-172.

Pi, M., \& Ha, S. (2020). Classification of subgroups of children with speech sound disorders: a preliminary study. Communication Sciences and Disorders, 25(1), 113-125.

Sosa, A. V. (2015). Intraword variability in typical speech development. American Journal of Speech-Language Pathology, 24(1), 24-35.

Sosa, A. V., \& Stoel-Gammon, C. (2006). Patterns of intra-word phonological variability during the second year of life. Journal of Child Language, 33(1), 31-50.

Sosa, A. V., \& Stoel-Gammon, C. (2012). Lexical and phonological effects in early word production. Journal of Speech, Language, and Hearing Research, 55(2), 596-608.

Teitzel, T., \& Ozanne, A. (1999). The development of consistency of speech production. 20th Annual Child Phonology Conference, University of Wales, Bangor.

Williams, P., \& Stackhouse, J. (2000). Rate, accuracy and consistency: diadochokinetic performance of young, normally developing children. Clinical Linguistics and Phonetics, 14(4), 267-293. 


\section{국문초록}

\section{말소리장애와 일반 아동의 정상적인 변이성과 병리적 비일관성}

\section{하승희}

한림대학교 언어청각학부, 한림청각언어연구소

배경 및 목적: 말소리 습득과정에서의 정상적인 변이성과 병리적인 비일관성을 구별하고자 일반 아동과 말소리장애 아동을 대상으로 낱말 산출의 일관성 및 정확성을 정량화하여 살펴보고, 언어학적 증상에 따라 분류한 말소리장애 하위유형별로 일관성 및 정확성 측 면에서 어떠한 특성을 보이는지 살펴보았다. 방법: 일반 아동 209 명과 말소리장애 아동 99 명을 대상으로 22 개의 낱말을 3 번씩 산출하 게 한 뒤 일관성과 정확성 여부를 바탕으로 아동의 반응을 4 가지 유형으로 분류하고 유형별 비율과 일관성 및 정확성 점수를 구하였다. 연령에 따라서 일반과 말소리장애 아동 간 차이가 있는지 살펴보고, 말소리장애 하위유형에 따라서 반응 유형이 어떠한지 살펴보았다. 결과: 일반과 말소리장애 아동은 전반적으로 일관적이고 정확한 반응을 가장 높은 비율로 보였다. 연령이 증가함에 따라 점진적으로 일관적이고 정확한 반응은 증가하고 부정확하면서 비일관적인 반응은 감소하였다. 일반 아동과 비교해 말소리장애 아동은 일관적이 고 정확한 반응의 비율은 유의하게 낮고 부정확하거나 변이적인 산출은 유의하게 높았다. 말소리장애 하위유형 중 조음장애, 음운지연, 일관적 음운장애는 공통적으로 일관적이고 정확한 반응의 비율이 가장 높게 나타났으나 비일관적 음운장애는 부정확하고 비일관적 인 반응이 가장 높아 다른 세 하위유형의 말소리장애 아동과 구별되었다. 논의 및 결론: 본 연구는 연령에 따른 정상적인 변이성의 발달 과정을 제시하고, 비일관적인 음운장애는 일반아동뿐만 아니라 다른 말소리장애 유형과도 다른 병리적인 비일관성을 보이고 있음을 제시하면서 말소리장애 감별 진단의 기반을 마련하였다.

핵심어: 말소리장애, 정상적인 변이성, 병리적 비일관성, 연령

본 연구는 한림대학교 교비학술연구과제(No. HRF-202003-010)에 의해 수행되었음.

\section{참고문헌}

김민정, 배소영, 박창일(2007). 아동용 발음 평가(APAC). 인천: 휴브알앤씨. 피민경, 하승희(2020). 말소리장애 아동의 하위 유형 분류를 위한 예비연구. Communication Sciences \& Disorders, 25(1), 113-125. 하승희, 서동기(2019). 말소리장애 감별 진단을 위한 조음 일관성 연구. Communication Sciences \& Disorders, 24(4), 1015-1025. 하승희, 김민정, 서동기, 피민경(출판 중). 한국 조음음운프로파일(K-APP). 서울: 휴브알앤씨. 한은지, 하지완(2017). 말소리장애 아동과 일반 아동의 조음복잡성에 따른 조음변이성 연구. Communication Sciences \& Disorders, 22(4), 772-783. 황진경, 하승희(2012). 2세 후반-4세 아동의 조음 변이성 연구. 언어청각장애연구, 17(3), 403-413.

\section{ORCID}

하승희(제1저자, 교신저자, 교수 https://orcid.org/0000-0003-2133-3720) 